\title{
Recent Lipid Membrane-Based Biosensing Platforms
}

\author{
Georgia-Paraskevi Nikoleli ${ }^{1, *(\mathbb{0})}$, Christina G. Siontorou ${ }^{2}$, Marianna-Thalia Nikolelis ${ }^{2}$, \\ Spyridoula Bratakou ${ }^{1}$ and Dimitrios K. Bendos ${ }^{1}$ \\ 1 Laboratory of Environmental and Sanitary Engineering, Department of Public Health, \\ Faculty of Health and Caring Professions, University of West Attica, 15771 Athens, Greece; \\ pepibrat13@hotmail.com (S.B.); dkbendos@teiath.gr (D.K.B.) \\ 2 Laboratory of Simulation of Industrial Processes, Department of Industrial Management and Technology, \\ School of Maritime and Industry, University of Piraeus, 18534 Pireus, Greece; csiontor@unipi.gr (C.G.S.); \\ m.nikolelis@gmail.com (M.-T.N.) \\ * Correspondence: dnikolel@chem.uoa.gr
}

Received: 29 March 2019; Accepted: 22 April 2019; Published: 27 April 2019

\begin{abstract}
The investigation of lipid films for the construction of biosensors has recently given the opportunity to manufacture devices to selectively detect a wide range of food toxicants, environmental pollutants, and compounds of clinical interest. Biosensor miniaturization using nanotechnological tools has provided novel routes to immobilize various "receptors" within the lipid film. This chapter reviews and exploits platforms in biosensors based on lipid membrane technology that are used in food, environmental, and clinical chemistry to detect various toxicants. Examples of applications are described with an emphasis on novel systems, new sensing techniques, and nanotechnology-based transduction schemes. The compounds that can be monitored are insecticides, pesticides, herbicides, metals, toxins, antibiotics, microorganisms, hormones, dioxins, etc.
\end{abstract}

Keywords: lipid film-based biosensors; nanotechnological platforms; graphene electrodes; $\mathrm{ZnO}$ nanowalls and nanowires; food toxicants; environmental pollutants; clinical analysis

\section{Introduction}

The early 1960's attempts to reconstitute lipid bilayers in vitro gradually established a lipid membrane technology path, which is quite intriguing, in the sense that the dynamic and complex nature of biological membranes could be actually simulated with a lipid solution, some skill and a set of affordable instrumentation, yet highly demanding in expertise when the extremely fragile lipid bilayer produced, freely suspended between two electrolyte interfaces, should remain intact for the duration of an experiment [1]. Nowadays lipid membrane constructs can be shaped in many architectures (bilayers, multilayers, mixed layers, branched, doped, nanodiscs, tethered, functionalized, etc.) to serve, efficiently and effectively, a dual purpose: analytical detection [2] and simulation studies [3]. Both research fields benefit from the capability to reproduce some properties of biological membranes and package them into sensing platforms for biosensor devices or membrane interaction studies, respectively. Interestingly, the former field uses the term artificial lipid membranes [2] while the latter exploits similar principles and methods to yield biomembranes or membrane mimics [3], the different connotations refer to the scopes of research and not the research tool per se.

The number of devices based on lipid membranes that were used to monitor food toxicants, environmental pollutants, and compounds of clinical interest has increased tremendously for the last two decades. During the last decade, a number of efforts to prepare stabilized lipid devices were successful and this has given the opportunity to construct biosensors to detect food toxicants and environmental pollutants in real samples and in the field. The advantages of lipid film devices are summarized as follows: The membranes have an appropriate biocompatible structure with fast 
response times, high sensitivity and selectivity, small size, portability, and provide advantages as compared with the bulky liquid chromatographic (LC) instruments. The new generation of stabilized lipid membrane nanosensors has the potentiality to construct site-specific analytical devices with respect to analytical performance, operational stability, and response.

Lipid membrane technology reduces the complex membrane properties and processes to well-controlled and defined interactions between biological moieties, lipids, and transducers (Figure 1). Although the very nature of biological membrane still remains elusive [4], it is easy to isolate specific membrane properties for drug permeability [5] or protein-lipid interaction studies [6], or even to control and manipulate nano-processes on the lipid bilayer by changing macro-parameters ( $\mathrm{pH}$, temperature, ionic strength, lipid composition, etc.) [7]. Biological moieties (enzymes, antibodies, receptors, ligands, DNA, etc.) can be easily immobilized on the surface of lipid membranes [2] or embedded into the lipid organization [6] using thermodynamically driven self-assembly processes or more precise techniques, such as patterning [8] or surface printing [9]. The lipid micro-environment presents a compatible setting for biological species to retain their full functionality while experimented upon. Further, the physical state of the lipid membrane offers an intrinsic signal transduction and amplification mechanism, perfectly fitted for electrochemical sensing: When the biological moiety, attached on or embedded in the membrane, interacts with the target analyte, lipid-protein and lipid-lipid interactions are affected to a degree sufficient to disrupt the lipid organization [1]; this affects the flux of ions through the membrane and can be readily detected as current alterations.

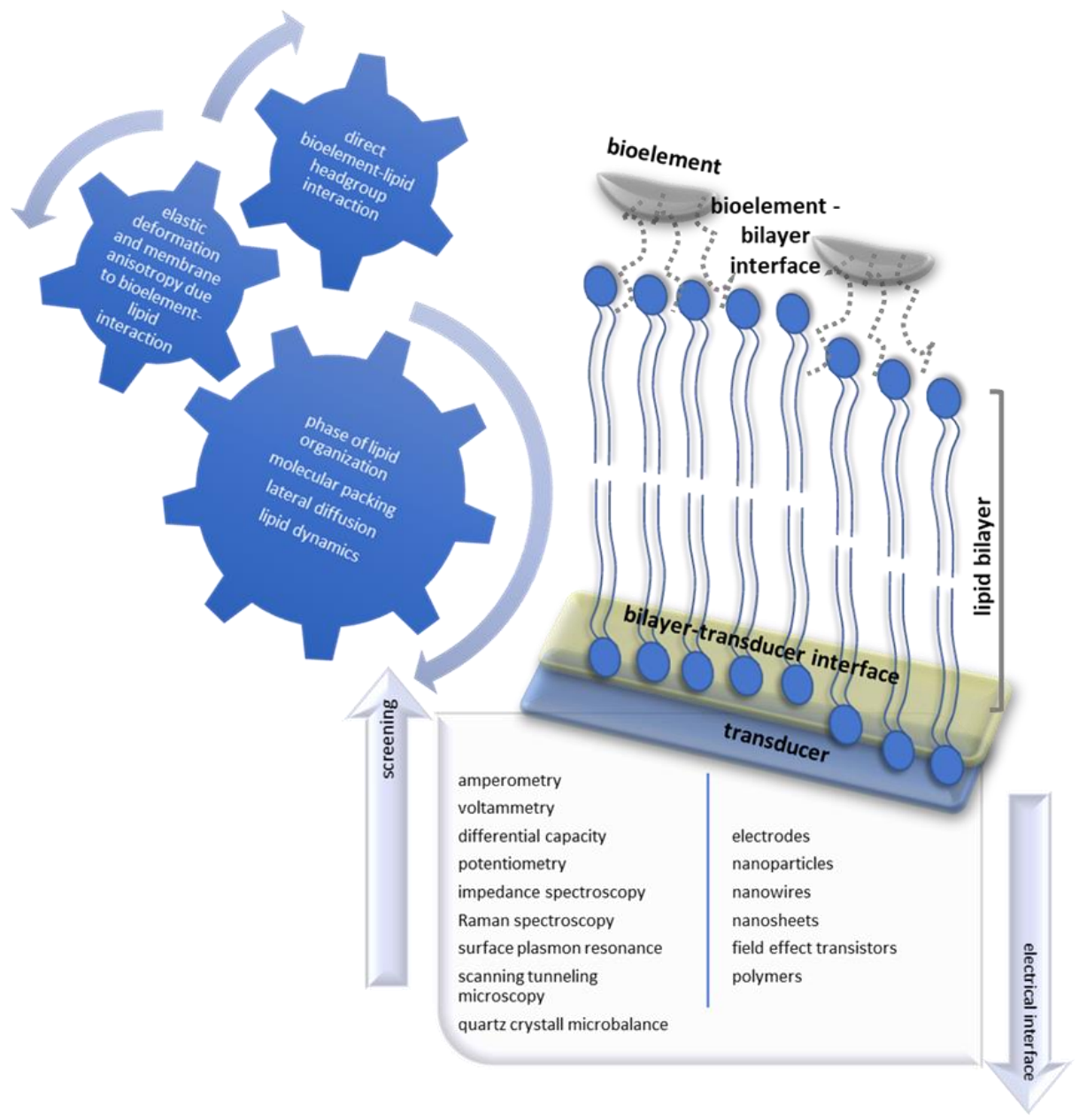

Figure 1. Simplified overview of the basic lipid membrane platform for biosensor development, illustrating, also, the critical physical chemistry that gears the biochemical information produced on the membrane surface for electrochemical transduction and the most common screening strategies employed. 
A quick glance at the history of the field reveals that the 1990's witnessed a dedicated and intense research towards stable lipid membrane constructs [1]. Efforts included a variety of fabrication procedures, supports, and materials [10]. However, as the structural stability of the membrane was increasing, its ability to reproduce the natural membrane function was decreasing and so did its analytical supremacy (high sensitivity and selectivity, low detectability, and fast response times) [10]. Nano-tools and new engineering concepts are now used in device engineering in order to simulate adequately membrane energetics and provide platforms that address certain requirements for practical implementation:

- Adequate robustness for long-term stability under storage and operation.

- Simple and non-expertise demanding reproducible fabrication.

- Stable membrane state, preferably liquid crystalline, that allows lateral mobility.

- Stable and reproducible membrane morphology, preferably defect-free for easier control on ion transport.

- Adequate hydration in the hydrophilic region in order to support protein-based interactions.

- Compatible coupling to transducers.

- Fit-for-purpose detection strategy that will ensure optimal detection without catastrophic perturbations of the lipid organization.

- Carefully managed strength of immobilized biology in order to avoid leakage but maintain functionality.

Lipid membrane technology adsorbed rapidly the scientific and technological output of many fields in order to evolve into the diverse cluster of today (Figure 2). This paper presents the electroanalytical aspects of artificial membranes, the processes and tools used for building membrane platforms, the current challenges and the future trends. What is expected in the near future is the market availability of these lipid-based sensing platforms for research and practical implementation.

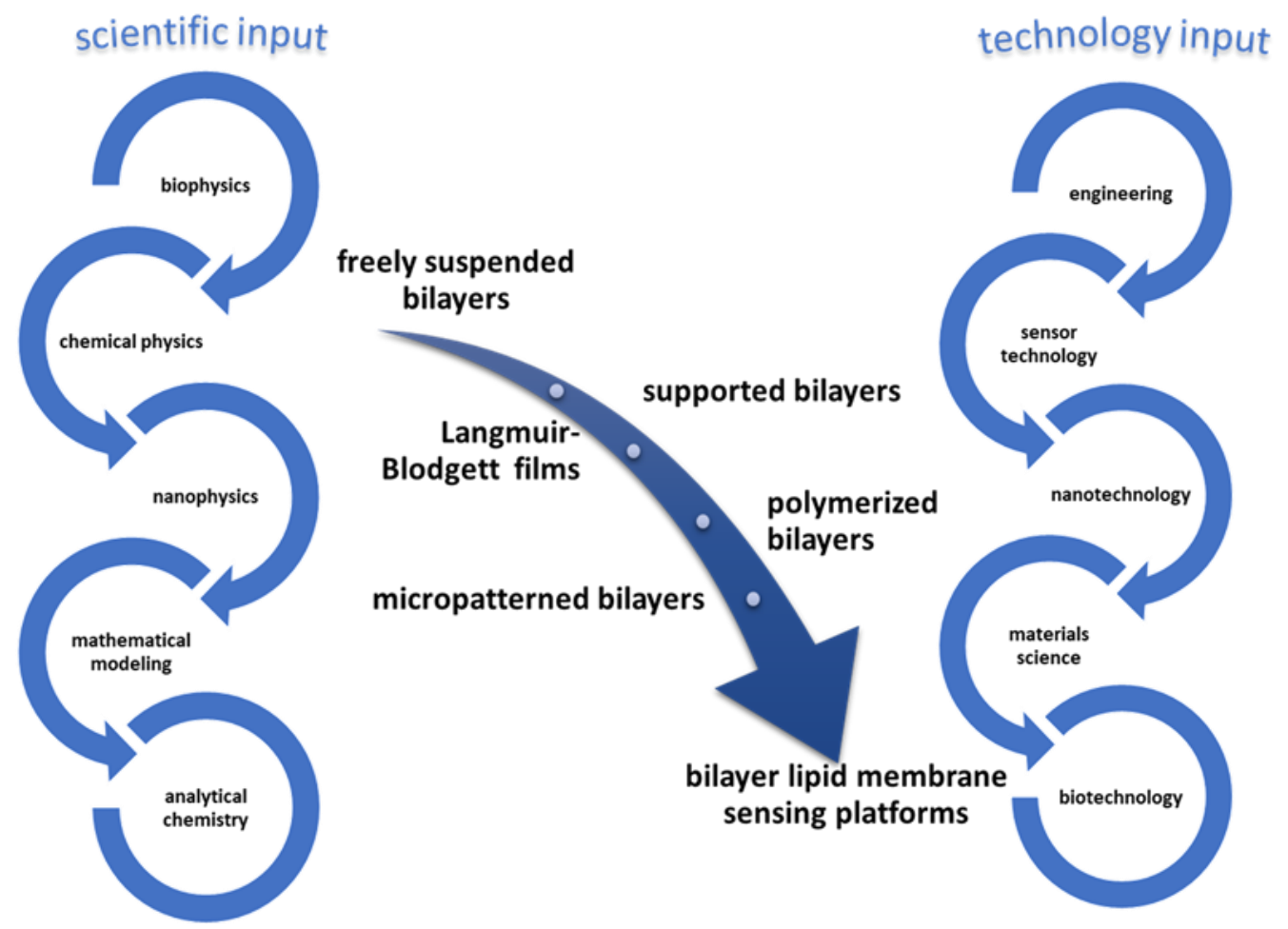

Figure 2. The science and technology input that enabled lipid membrane technology to progress from freely suspended fragile bilayers (black lipid membranes) to rugged nanopatterned sensing platforms. 


\section{The Electroanalytical Aspect of Lipid Membrane Biosensors}

The dynamic nature of the lipid organization into sheets provides the mechanisms for the translation of the biochemical information into an electric signal. The simplest set-up uses a lipid bilayer formed in a $\mu \mathrm{m}$-aperture between two electrolyte solutions (Figure 3A) under an external voltage. This organization is maintained through a careful balance between the bilayer and its surrounding micro-environment, expressed by certain membrane properties that are not easily accessible, yet controllable (to a certain extend) by lipid composition, electrolyte solution, $\mathrm{pH}$, temperature, and the value of external voltage [10] thickness, surface charge density, fluidity, dipolar potential, and transmembrane potential. These properties collaborate to allow a small but measurable ion flux through the membrane; any alteration of any of these parameters alters membrane permeability and changes its electrostatics in a way analogous to the intensity of the cause of perturbation (i.e., the concentration of the target analyte). It follows that the mechanism of signal generation corresponding to an external stimulus involves manipulations of membrane permeability.
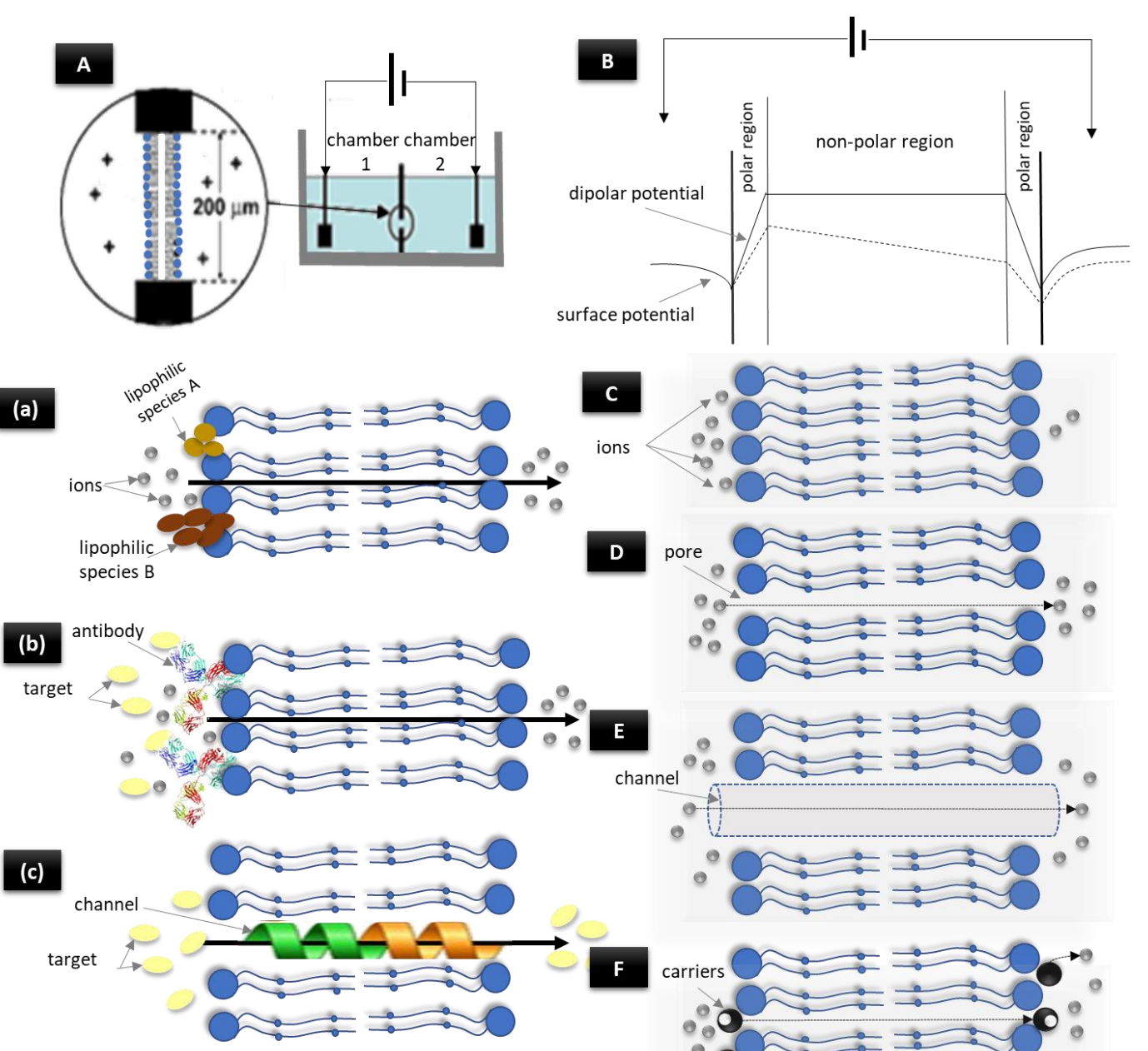

pore

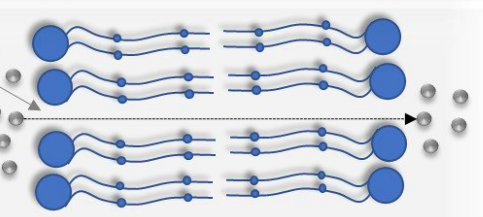

\section{(b)}

$\mathbf{E}$
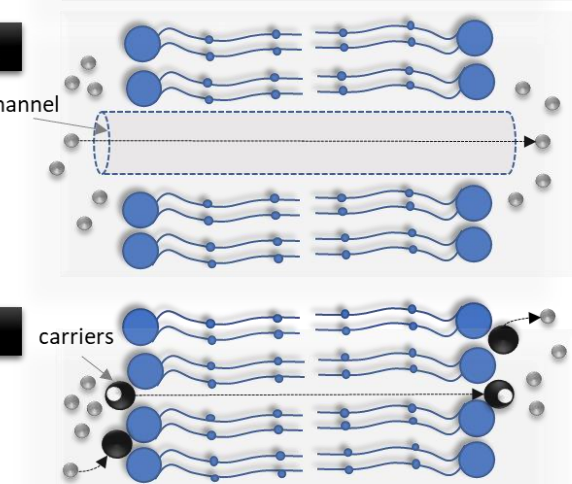

Figure 3. The electroanalytical aspect of artificial bilayer lipid membranes: Simplified schematic of the experimental set-up (A); potential distribution across the bilayer (B); overview of the principle mechanisms for signal generation $(\mathbf{C}-\mathbf{F})$; and the main biosensing strategies employed $(\mathbf{a}-\mathbf{c})$. For details see text.

Ionic flux through the membrane can be the result of a chemical gradient (Figure 3C); it depends on diffusion coefficients [2] and it can be thermodynamically driven by high mobility ions and 
the presence of a large number of ions on one electrolyte-membrane interface [5]. Higher values may be recorded in the presence of transient or permanent pores [10], induced by external voltage (electroporation) [11], surface charge density fluctuations [6], or molecular surface perturbations [8] (Figure 3D). Pore formation depends on lipid composition and molecular packing and fluidity of the bilayer [10]; it can be controlled by $\mathrm{pH}$, temperature, and divalent cations. Lipophilic compounds, for example, are adsorbed onto the membrane surface to alter lipid packing that modifies ion fluxes (Figure 3A(a)); the phenomenon becomes more prominent if aggregation of the lipophilic molecules follows initial adsorption. In a complex mixture of species with slightly different partition coefficients (lipophilic species A and B in (Figure 3A(a)), discrimination is possible [12]. Further, antigen-antibody complementation on the membrane surface may induce changes in the interaction between the antibody and the lipid headgroups, also, resulting in transient pore formation [13] (Figure 3A(b)). Enzyme-based systems operate on similar principles, where the most common permeability regulator is surface charge density [14]. Notwithstanding, protein channels (e.g., gramicidin or alamethicin) that span the bilayer can provide the means for a vast ion flux increase (Figure 3E); channels can be controlled by electrolyte composition [15]. Similarly, carriers (e.g., valinomycin) can enhance permeability, provided a fluid bilayer is maintained (Figure 3F); mobility can be controlled by $\mathrm{pH}$, ionic strength, and lipid composition [16] (Figure 3A(c)).

As the bilayer, in its suspended architecture, forms two interfaces with the electrolyte, the alterations of potential across the bilayer can be monitored. The electric field of a bilayer is the sum of the potential drop across the membrane (transmembrane potential) due to chemical gradients between the two electrolyte interfaces, the potential drop in the diffuse part of the electrical double layer (surface potential) due to surface ionization and screening by electrolyte ions and the voltage drop across the interface (dipolar potential) due to the alignment of the electric dipole moments in the membrane-water interface (Figure 3B) [10]. A two-electrode system can be used to measure the transmembrane potential, typically found to be ca. $70 \mathrm{mV}$ at rest [10]. Many studies have shown that the transmembrane potential regulates voltage-sensitive phenomena for ion transporters [16], channels [17,18], or gating-charge controlled receptors [19].

The dipolar potential, on the other hand, cannot be accessed directly. Voltage-sensitive fluorescent membranes have been used to probe hydration and polarity of bilayers [20], record potential changes [21] or the strength of the electric field [22]. The relation between the dipolar potential and the membrane permeability remains unclear as to which regulates what [23], but it has been shown that surface tension increases reduce the value of the dipolar potential due to changes in lipid packing and in lipid-bound water molecules [24], this yields a mechanical sensitivity for the bilayers.

Following the Gouy-Chapman-Stern model, the bilayer can be seen as a plate capacitor, where capacitance measurements can be used to estimate membrane area, thickness, and surface potential. Typical values within the range of $0.5-0.8 \mu \mathrm{F} \mathrm{cm}^{-2}$ have been reported. Freely suspended bilayers can be represented by the simple circuit shown in Figure $4 \mathrm{a}$, but circuitry modeling may be quite complicated to include more elements (electrodes, interfaces, etc.) in order to account for bias [25] or to represent complex platforms, such as tethered bilayers [11], unanchored (Figure 4b) [25] or anchored membranes (Figure 4c) [17] on electrode surfaces, metal-supported membranes [25], polymer supported bilayers [26], or high density biosensor arrays [27]. These approximations can lead to misestimating, unless interfacial molecular structure and hydration are taken into account [10].

In non-Faradaic transduction, the estimation of capacitance is well-suited for surface characterization. Faradaic responses (i.e., from redox proteins) rely on electron transfer across the bilayer, depending on solution $\mathrm{pH}$ and ion concentration, temperature, lipid charge, and lipid concentration. Monte Carlo simulations [28] and molecular dynamics algorithms [24] have been developed for electrochemical parameter calculations and implemented successfully in suspended bilayers. The supported formats present certain problems in the analysis of the membrane under varying conditions, as the pressure-area isotherms used cannot account for area and particle number 
variations at the same time [29]. Further, permeability models of freely suspended membranes have to be also considered for data interpretation.

Impedance measurements have shown that long-range electrostatic attraction and short-range hydration repulsion dominate in unanchored membranes, whereas short-range van der Waals forces become significant at anchoring [25]. Additionally, in mixed bilayers with charged and uncharged lipids, the packing density of the lipid molecules may alter hydration repulsion and increase the number of pores in the membranes, thus reducing the value of its resistance [30].
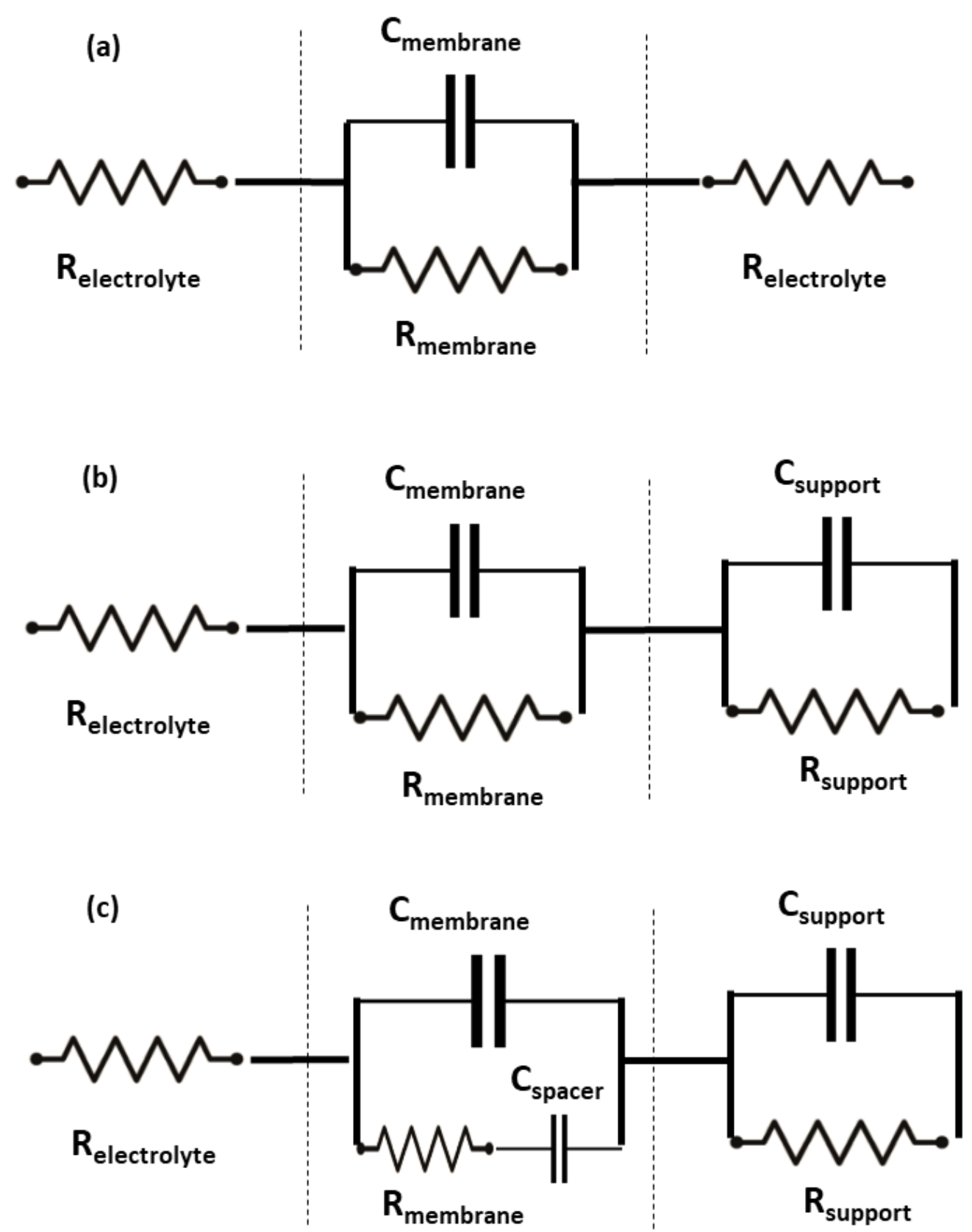

Figure 4. Equivalent circuit models for (a) suspended bilayer (i.e., with no direct contact with any electrode); (b) supported unanchored bilayer (i.e., floating on the surface of an electrode); and (c) anchored bilayer (i.e., through a spacer). The serial resistance $R_{\text {electrolyte }}$ corresponds to the ohmic behavior of the electrolyte solution, whereas the capacitance $C_{\text {membrane }}$ in parallel with $R_{\text {membrane }}$ represents the bilayer system. In the case of anchored membranes, the spacer region contributes its own constant-phase element; Cspacer indicates the electrochemical behavior of spacer and the water layer that separates the membrane from the surface of the electrode. 
Another inter-related critical parameter of membrane electrochemistry, especially as regards the modulation of permeability, is the phase shifting of the lipid sheets. Temperature changes affect the order of lipids and result in the structural phase transition of the bilayer: At low temperatures, the bilayer is in the gel phase (very packed with minimum diffusion of lipid molecules), whereas as temperature increases lipid packing becomes looser to reach a liquid crystalline phase [31]. The ability to modulate phase shifting upon binding of the analyte is another strategy in biosensing; biochemical interactions (i.e., nucleic acid interactions) on one side of the membrane may induce phase shifting, transient or permanent, which alters membrane permeability [32]. The use of mixtures of lipid solutions to fabricate membranes with domains of different structural phase transition temperatures [33] may, indeed, provide interesting sensing platforms and the capability of array engineering in small spaces. Despite, evidence suggests that the immobilization of bioelements on one side of the bilayer disturbs membrane symmetry and may induce budding in the domain of interaction [34], suppressing phase separation, unless interaction perturbs the hydrophobic region of the membrane. At any case, bioelement-target analyte interactions, disturb bioelement-lipid interactions that could allow micro-phase separation to occur.

When designing a lipid membrane platform for biosensing, the modulation of the interplay between electrochemical parameters for enhancing signal generation should also take under consideration membrane stability. Any change of electrical potential, surface tension, surface charge density, etc., may increase the free energy of the system, leading to molecular re-arrangement propagating to rupture [35]; the former does not affect membrane functionality critically but the latter is catastrophic. This implies a very careful trade-off between sensitivity and analytical range: Extremely sensitive biosensors work reliably in narrow analytical ranges [1]. In applications that may require broad detection ranges (e.g., environmental monitoring), the sensitivity level should be compromised.

\section{Lipid Membrane-Based Biosensing}

Methods and techniques for bilayer reconstitution have evolved considerably over time. Initial efforts to suspend the bilayer between two electrolyte solutions using the painting of the lipid solution over an aperture (Figure 5a) gave solvent-containing membranes at very low success rates [10]. Solvent-less forms could be produced with the expertise-demanding monolayer folding technique (Figure 5b), or the tip-dip method for short-lived bilayers (Figure 5c). These techniques produce bilayers that are accessible from both sides to permit the monitoring of ionic and molecular transport across the membrane.

Supported lipid bilayers (sBLMs) can be constructed with a variety of methods. Self-assembly on a metal tip (Figure 5d) yields extremely rugged sensors, even for practical use [36]. Vesicle fusion, on the other hand, is very popular in membrane studies (Figure 5e). This method offers many options for bioelement immobilization: Incorporation of bioelements into the liposomes prior to their spreading, their addition during vesicle spreading, or after the formation of the bilayer [37]; the process is strongly driven by liposome-substrate ionic interactions and it is not easy to control. However, the close proximity of the bilayer to the support lessens options for both, biochemical strategy and transducer coupling. Transmembrane proteins cannot be used as bioelements, as the metal substrate does not permit ion translocation across the lipid bilayer [10]. In effect, only electrochemical and surface interrogation techniques may be utilized for signal transduction $[38,39]$. 


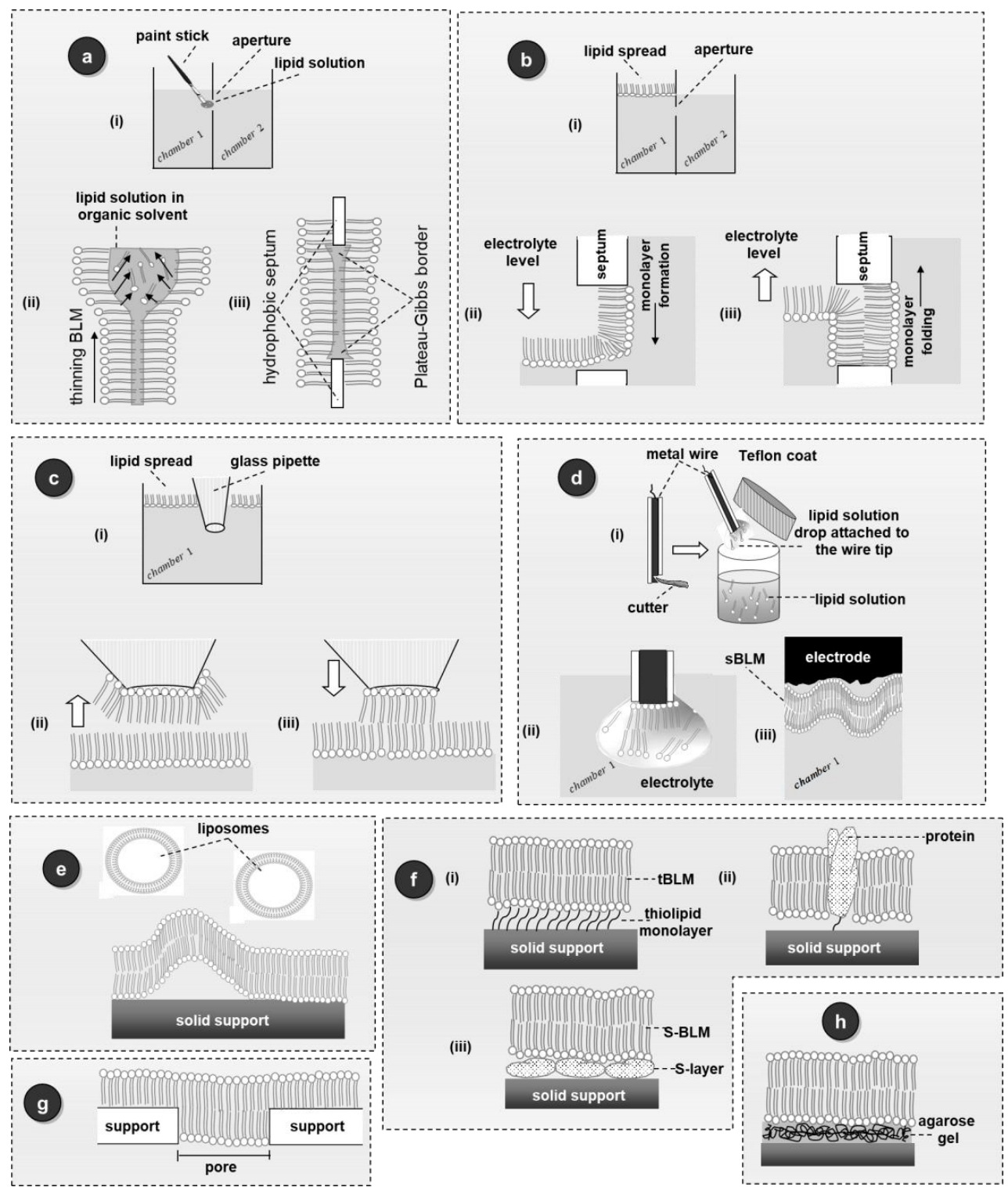

Figure 5. Methods for bilayer formation. (a) Lipid painting technique: (i) A hydrophobic septum that separates two electrolyte chambers is punched to produce an aperture which is painted with lipid in n-decane. (ii) The lipids are arranged so as to protect the hydrophobic tails and the membrane is compressed laterally by the hydrostatic pressure difference across the film. (iii) Bilayer Lipid Membrane (BLM) thinning pushes the solvent towards the annulus at the edge of the aperture (Plateau-Gibbs border). (b) Monolayer folding: (i) A lipid monolayer is spread onto the surface of the electrolyte. (ii) The electrolyte in one chamber is gradually removed, driving the formation of a monolayer around the aperture. (iii) The chamber is gradually refilled with the electrolyte in order to allow the zipping of the second monolayer. (c) Tip-dip: (i) The tip of a glass pipette is immersed in electrolyte solution, and lipids are spread on the surface of the electrolyte. (ii) Raising the pipette slowly, allows a monolayer to attach on its tip. (iii) When re-immersed, the second monolayer is attached. (d) Self-assembly on metal support: (i) A freshly tipped electrode is dipped in lipid solution. (ii) When it is immersed in electrolyte, a lipid monolayer is pushed onto the tip. (iii) Gradually, lipids are attracted and form the second monolayer on top (s-BLM). (e) Vesicle fusion: when lipid vesicles come in contact with an oppositely-charged solid support, they rupture a form spontaneously a bilayer. (f) Tethering: A bilayer may be tethered by thiolipids (i), proteins that span the membrane (ii), or proteins that support the membrane (iii). (g) Supporting on porous materials. (h) Gel-cushioning that also serves as a reservoir for ions. (Reprinted from [10] with permission by John Wiley and Sons). 
Supported but floating membranes can be produced through tethering (Figure $5 f$ ). In that way, an ionic reservoir beneath the bilayer is made available and the embedded proteins can be kept away from the support [40]. The architecture; however, of the platform, is complex in order to isolate the tethering layer from water, but not the bilayer [11]; ion-channel recordings require high resistance membranes [41] or the use of protein supports [42]. Other approaches involve the formation of membranes on porous substrates, like alumina [43], glass microfiber [44], polycarbonate [45], or Teflon [46]. A hybrid structure is produced with part of the membrane covering the pores and the rest lying on the solid surface (Figure 5g); the analytical useful part of the membrane is confined over the pores, giving rise to a network-like architecture of mini-membranes that can accommodate more bioelement molecules within a given area, as compared to a single membrane. Studies have shown that higher the thickness of the material and the smaller the pore size, the higher the stability of the membrane [44]. It, also, turned out that stray capacitance and leakage current values are lower in such constructs [41], allowing for chip integration.

Polymer-supports (Figure 5h), including chitosan [47], hydrogels [48], or dextrans [30], cushion membranes to simulate the cytosol of the cell, to insert a hydrophilic area between the membrane and the substrate and to give membranes good electrical sealing for protein studies. However, conditions should be optimized for surface interrogation: Substrate thickness should be low and roughness should be high, whereas the thickness of the gel should be adequate to yield a smooth plane [48]. Lengthy experiments may be complicated by gel cracking due to aging and membrane fluidity decay [49].

Complex architectures can be achieved by Langmuir-Blodgett membranes, formed by stacking monomolecular (LB) films on solid supports. The thickness and the size of the layers can be controlled, lipid alignment can be tuned, mixed membranes, even with varying composition, can be produced, and large area patterning is possible [50]. These structured layers are used in engineering biological interfaces in molecular electronic devices [51].

Mechanically stable membranes can be produced via polymerization or microfabrication. UV irradiation or thermal polymerization involves the spread of a lipid solution over a polymer base [52]; if UV-assisted, bioelements can be added in the lipid solution or after the membrane formation; if temperature-assisted, bioelements are added only after membrane formation to avoid denaturation. Automated lipid assembly into vertically-oriented micro-bilayers has been extensively used in chip integration [53]. Further, microfluidic devices drive bilayer assembly through droplet collisions. Droplet interface bilayers can assume higher structures and seeded with pores or channels to simulate complex natural membrane systems and intracellular signal transduction cascades [54]. Microscope-monitored nanotopography forms bilayers in nano-pits [55]. Using a combination of Langmuir-Blodgett technology and vesicle fusion, the whole process can be fully automated, provided humidity and temperature are optimized. Dip-pen nanolithography, uses an atomic force microscope to deposit lipids on substrates and control their interaction [56]. Multicompositional arrays can be; thus, prepared with minimal effort and high reproducibility [57].

The range of biochemical interactions that have been monitored with these lipid membrane platforms is vast, indeed, including enzyme-substrate systems [58], redox-active proteins [59], immunological assemblies [60], nucleic acid and nucleotide-assisted detection or sequencing [61], pore forming toxins [59], ion channels [62], ligand-coupled receptors [63], hormonal function [62], inorganics, and chemical pollutants [64].

\section{Methods for the Preparation of the Most Important Platforms of Stabilized Biosensors Based on Lipid Membranes}

During the last decade, the construction of stabilized lipid film-based biosensors that are not prone to electrical or mechanical shock and are stable outside an electrolyte solution has been the investigation of a number of reports; these investigations will provide devices that can be commercialized due to their practical applications. Nanotechnological advances have provided a route to construct devices so that their size is less than $1 \mu \mathrm{m}$ size and; therefore, belong to the class of nanosensors. Below we 
describe the techniques for the construction of this class of biosensors based on lipid films, which have a number of advantages such as ease of construction, rapid response times, small size high selectivity and sensitivity, and, most importantly, are stable outside an electrolyte solution that will allow them to be eventually be commercialized.

\subsection{Stabilized Lipid Films Formed on a Glass Fiber Filter}

The route of the construction of stable in electrolyte lipid films was first reported by Nikolelis et al. and these films were formed on glass fiber filters $[65,66]$; this has permitted a large number of applications in real samples (i.e., the continuous monitoring of aflatoxin $\mathrm{M}_{1}$ in dairy products [65]). The lipid films were prepared on a glass fiber disk (ie., GF/F glass microfiber), $0.9 \mathrm{~cm}$ in diameter and $0.7 \mu \mathrm{m}$ nominal pore size $[65,66]$.

The method of preparation of these stable in electrolyte lipid films has extensively been described $[65,66]$. A diagram of the set-up that has been used is given in Figure 6. The stabilized in electrolyte solution lipid membranes were formed by established procedure as follows [65,66]: A total of $10 \mu \mathrm{L}$ of a lipid solution in hexane was placed with a microliter syringe at the electrolyte surface in the cylindrical cell. The level of this solution was brought below the $0.32 \mathrm{~mm}$ hole and then raised again within a few seconds. Once the lipid films were formed, the current was brought down at the pA level and gramicidin D was used to provide the bimolecular structure of these bilayers.

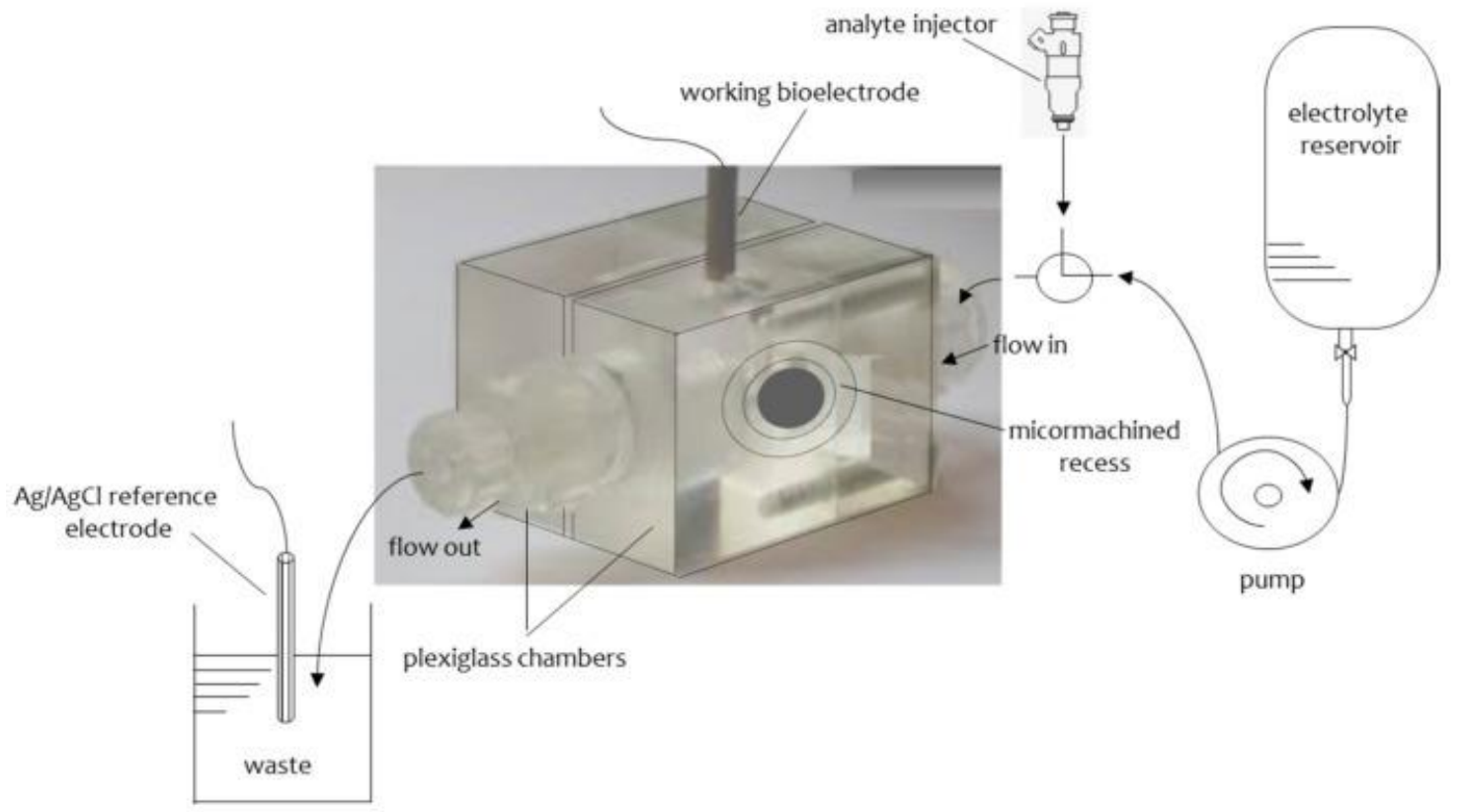

Figure 6. A diagram of the set-up for the formation of lipid membranes that were stable in electrolyte solution (from [64]).

\subsection{Polymer-Supported Bilayer Lipid Membranes}

The polymeric stable in air lipid membranes were constructed as previously reported $[67,68]$. UV irradiation and not heating at $60^{\circ} \mathrm{C}$ is preferable, because the latter deactivates protein molecules. Differential scanning calorimetry and Raman spectrophotometry have shown that $4 \mathrm{~h}$ is required to finishing the polymerization.

The construction of these devices has been described in the literature and briefly is as follows [67,68]: A total of $0.07 \mathrm{~mL}$ of methacrylic acid, $0.8 \mathrm{~mL}$ of ethylene glycol dimethacrylate, $8 \mathrm{mg}$ of 2,2'-azobis-(2-methylpropionitrile), and $1.0 \mathrm{~mL}$ of acetonitrile are added in $0.8 \mathrm{~mL}$ of a suspension that contains $4 \% \mathrm{w} / \mathrm{v}$ DPPC in a solvent of $\mathrm{n}$-hexane (which evaporates and the lipid membranes are "solvent-free"). Then nitrogen is allowed to pass through this mixture and a sonication follows. 
A volume ot $0.15 \mathrm{~mL}$ of this suspension is placed on the microfilter (Whatman Inc., Maidstone ME14 2LE, UK, GF/F microfiber glass disk having diameter of $0.9 \mathrm{~cm}$ and pore size of $0.7 \mu \mathrm{m}$ ) and the filters are irradiated with a UV deuterium lamp. The experimental instrumentation was the same as in Figure 1. These membranes were stable in storage in air for at least one month and can be used in flow-through experiments.

\subsection{Polymeric Lipid Membranes Supported on Graphene Microelectrodes}

Graphene nanomaterials have been used in biosensors because of their advantages, such as enhanced physicochemical properties (mechanical, electrical and thermal), large surface-to-volume ratio, high biocompatibility, and low toxicity. The large surface-to-volume ratio minimizes the device size and provides rapid response times and lower sensitivity without biofouling. Our group has constructed a device that was composed from a stabilized lipid membrane on a copper wire that contained graphene nanosheets $[69,70]$. These nanodevices have been used for the rapid determination of food toxicants, environmental pollutants, and compounds of clinical interest [71-73].

The preparation of graphene microelectrodes has been extensively described in the literature [71-73]. N-methyl-pyrrolidone (NMP) was mildly sonicated for $180 \mathrm{~h}$ and centrifuged at $700 \mathrm{rpm}$ for $2 \mathrm{~h}$ which provides a homogeneous dispersion $(\sim 0.4 \mathrm{mg} / \mathrm{mL})$. This dispersion was poured onto a copper wire $(0.25 \mathrm{~mm}$ in diameter), which was placed on a glass microfiber filter and the solvent was evaporated. The copper acted as the connection for the electrochemical experiments.

The method of preparation of the lipid membrane biosensors was previously described in detail [71-73]: The stabilized lipid films were prepared by polymerization, as described above.

The "receptor" molecules were incorporated in these lipid film devices prior to polymerization by injecting $15 \mu \mathrm{L}$ of the "receptor" suspension on the polymerization mixture. The filter-supported polymeric BLMs were finally mounted onto the copper wire that contained the graphene nanosheets.

\subsection{Polymer Lipid Films Supported on ZnO Microelectrodes}

Nanostructured $\mathrm{ZnO}$ is a promising material for the construction of nanoelectrodes for food, environmental, and clinical applications because it has a large number of advantages, such as low cost, ease of preparation, biocompatibility, and catalytic surface activity. Other advantages include high isoelectric point (IEP), nanostructured $\mathrm{ZnO}$ electrodes have high sensitivity and small size, high surface area, and high electrical transport. Note that the electrical transport $\mathrm{ZnO}$ properties depend on its crystal structure, surface polarity, etc., and these properties can be modeled. The IEP of ZnO is 9.5 which is higher than the IEP of a large number of biomolecules and; therefore, it can be used as a matrix to immobilize these compounds through electrostatic bonding. $\mathrm{ZnO}$ nanoelectrodes have widely been used for the construction of devices to detect important analytes such as cholesterol, glucose, L-lactic acid, uric acid, metal ions, and $\mathrm{pH}$.

\subsubsection{Potentiometric Biosensors Based on ZnO Nanowalls and Stabilized Polymerized Lipid Film}

The unmodified $\mathrm{ZnO}$ nanowall electrodes on an aluminum ( $\mathrm{Al}$ ) foil can be constructed by the well-known sonochemical technique of Nayak et al. [74].

The preparation of the polymerized stabilized lipid films for the determination of cholesterol was previously described [75]. Cholesterol oxidase was incorporated in these lipid membranes prior to polymerization by spreading, on the microfilter, $15 \mu \mathrm{L}$ of the enzyme suspension with the polymerization mixture using a microliter syringe.

The final stage to construct the device was to encapsulate the filter-supported polymerized lipid film onto the wire containing the $\mathrm{ZnO}$-nanowalls electrode. Figure 7 shows a simplified diagram of the device. 


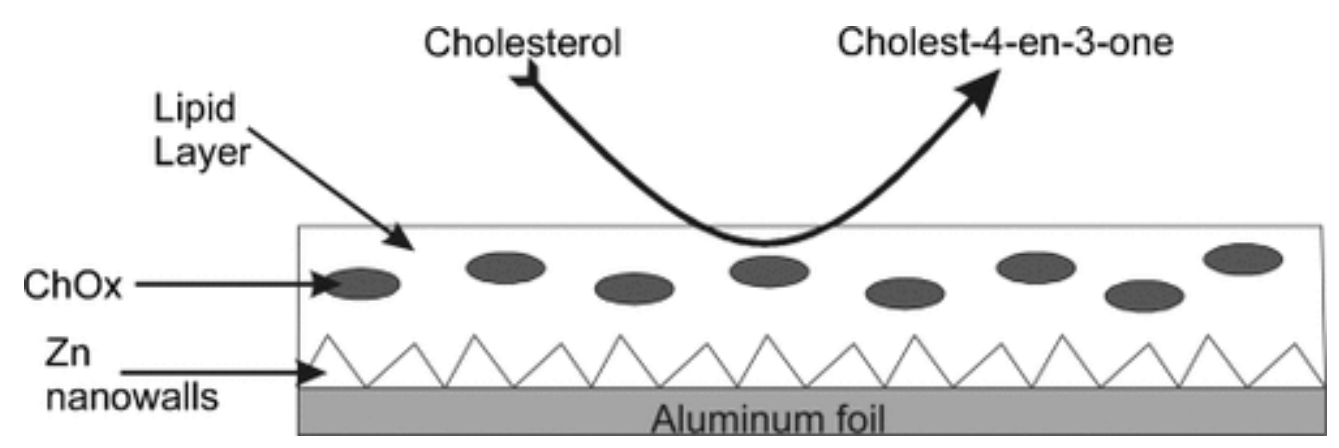

Figure 7. A simple diagram of the device design (from [75] with permission).

\subsubsection{Potentiometric Biosensors Based on Lipid Stabilized Membranes ZnO Nanowires}

The sensor electrodes were constructed following the method as previously [76]. The plastic substrate was affixed on a support in the vacuum chamber of an evaporator. Firstly, the titanium film was deposited (thickness ca. $10 \mathrm{~nm}$ ) and then $50 \mathrm{~nm}$ of gold was deposited on the surface of the plastic substrate. The gold coated electrode ( $4 \mathrm{~cm}$ long and $1 \mathrm{~mm}$ width) was rinsed with acetone and then by de-ionized water and dried at room temperature. A chemical approach was used to prepare the $\mathrm{ZnO}$ nanowires on the electrode [77]. The electrode was inserted twice into a solution that contained zinc acetate $(2 \mathrm{~min})$ and then was dried in the air. The electrodes then were inserted in a $025 \mathrm{M} \mathrm{Zn}$ $\left(\mathrm{NO}_{3}\right)_{2} \cdot 6 \mathrm{H}_{2} \mathrm{O}$ solution that contained $0.025 \mathrm{M}$ hexamethylenetetramine and placed in an oven $(2-4 \mathrm{~h}$, $90^{\circ} \mathrm{C}$ ). The $\mathrm{ZnO}$ nanowires were finally rinsed with de-ionized water and dried at room temperature. The diameters were $80-150 \mathrm{~nm}$ and were uniform.

The enzyme (uricase) was incorporated in the lipid membranes prior to polymerization as previously described [78]. Construction of the uricase device was finalized by encapsulation of the filter-supported polymerized lipid film onto copper wire containing the $\mathrm{ZnO}$ nanowires.

\section{Practical Applications of Lipid Membrane Devices in Food, Environmental, and Clinical Analysis}

\subsection{Applications of Lipid Film Sensors Based on Glass Microfilter}

An atrazine lipid film biosensor was reported in the literature, which was based on microfiber glass filters between two Saran-Wrap ${ }^{\mathrm{TM}}$ partitions in which the lipid was deposited [79]. A transient ion current signal (duration of seconds) was the result of interactions of atrazine with the lipid membranes and appeared within $1 \mathrm{~min}$ following the injection of atrazine into the bulk electrolyte solution. The introduction of an anionic lipid (35\% DPPA) in membranes and of calcium ions in the electrolyte solution increased the sensitivity of the technique. Similarly, the use of platelet-activating factor (PAF; an ether analog of PC) in membranes increased greatly the sensitivity.

A Flow Injection Analysis (FIA) technique of mixtures of the triazine herbicides simazine, atrazine, and propazine, using a mixture of PC (Phosphatidyl Choline)/ Dipalmitoylphosphatidic Acid (DPPA) in glass fiber filter-supported lipid films, was reported in the literature [12]. When a sample containing a mixture of these herbicides was injected into the flowing carrier $\mathrm{KCl}$ electrolyte solution, a transient ion current signal (duration of seconds) appeared in less than $2 \mathrm{~min}$ following the injection. The peak heights of these signals were linearly correlated to the herbicide concentration, $\mu \mathrm{M}$ detection limits. The signal did not decrease but rather remained practically constant, even when repetitive cycles of injections were performed. The time of appearance of the transient signal varied on the hydrophobicity of each herbicide and increased to the order of simazine, atrazine, and propazine, thus allowing the simultaneous determination and analysis of these triazines in mixtures. 


\subsection{Applications of Lipid Film Devices Based on Polymeric Lipid Membranes}

The stable in air lipid film devices were applied for the determination of carbofuran using flow injection analysis (FIA) [14]. The technique was based on the degree of inhibition and reactivation of enzyme upon substrate injections. Carbofuran could be detected between $10^{-7}-10^{-9} \mathrm{M}$. Interference studies were made and involved proteins and lipids that are food components. No interferences were noticed from these compounds. The device was evaluated/validated using real food samples (i.e., fruits, vegetables, and dairy products). The recovery studies have shown satisfactory results between $96 \%$ and $106 \%$, which shows that there are no interferences from the sample matrix.

A synthetic "receptor" (calixarene) was prepared and immobilized on lipid membranes on glass microfiber filters. Calixarene was inserted into the lipid structure and provided a signal which was adequate to rapidly determine insecticides rapidly, with a sensitive and selective response, and was used to determine these compounds in real samples of fruits and vegetables [80]. Similar devices were constructed to selectively and rapidly determine food hormones (i.e., naphthalene acetic acid) in fruits and vegetables [81] and a zinc in water [82].

\subsection{Applications of Graphene Based Devices}

A potentiometric urea lipid membrane-based mini-sensor on graphene has been reported recently [69]. A potentiometric urea device based on lipid film technology on graphene nanosheets has been constructed; a simplified set up of this biosensor is shown in (Figure 8). The main characteristics of this biosensor are excellent reproducibility, sensitivity, selectivity, reusability, and rapid response times; the slope of the electrode is ca. $70 \mathrm{mV} /$ decade over the urea logarithmic concentration range, which can be determined from $1 \times 10^{-6} \mathrm{M}$ to $1 \times 10^{-3} \mathrm{M}$.

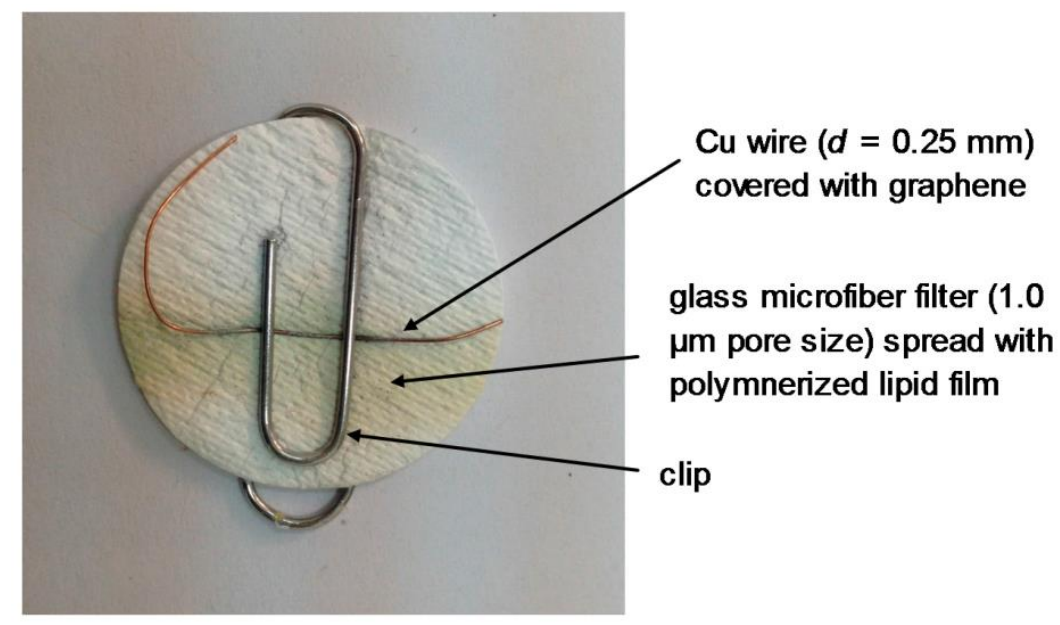

Figure 8. Picture of the lipid film device on graphene mini-electrode, which was used for the potentiometric detection of urea (reprinted from ref. [83]).

A nanosensor for naphthalene acetic acid (NAA) was reported in the literature and was based on polymerized stable-in-air lipid film devices, in which auxin-binding protein 1 receptor was co-deposited with the lipid film [71]. The sensor was evaluated in real samples of fruits and vegetables. Using a flow-through experimental set up, NAA was injected into the flowing $0.1 \mathrm{M} \mathrm{KCl}$ electrolyte solution and the flow was stopped. An ion current transient was obtained; the peak height was related to the concentration of NAA with $\mathrm{mM}$ detection limits and analysis times of ca. $5 \mathrm{~min}$. Interference studies have shown no interferences from compounds normally found in foods and vegetables (e.g., lipids, proteins, ascorbic acid, etc.). The sensor has been used to determine NAA in fruits and vegetables with quite satisfactory results.

A potentiometric carbofuran mini-sensor on graphene, in which lipid films were polymerized, was provided in the literature [70]. This device was applied to construct a carbofuran chemical sensor by 
co-depositing resorcin[4]arene selective receptor. The detection limits were at the $\mathrm{nM}$ level, with times of response of $20 \mathrm{~s}$. The device was constructed easily and showed excellent characteristics, such as good reproducibility, reusability, selectivity, long shelf life; the electrode slope was $59 \mathrm{mV} /$ decade and carbofuran was logarithmically related in the range $10^{-6}$ to $10^{-3} \mathrm{M}$.

The electrochemical interactions of cholera toxin with polymerized lipid films with incorporated ganglioside GM1 was reported in the literature [84]. An injection of cholera toxin in the flowing streams of a $\mathrm{KCl} 0.1 \mathrm{M}$ carrier electrolyte provided a current signal. The peak height of the ion current signal was correlated with the concentration of cholera toxin in the sample solution, with detection limits of $0.06 \mu \mathrm{M}$.

The response times and detection limits were improved using polymerized lipid membranes on graphene nanosheets (i.e., response times of $5 \mathrm{~min}$, and detection limits of $1 \mathrm{nM}$ ) [72]. The construction of this sensor was easy and the sensor has shown good reproducibility, reusability, selectivity, long shelf life, and sensitivity of $60 \mathrm{mV} /$ decade of toxin concentration. The method was applied in lake water samples.

An electrochemical biosensor for the determination of saxitoxin based on graphene nanosheets with stable-in-air lipid membranes and immobilized anti-Saxitoxin (STX) was provided in the literature [73]. An excellent selectivity, sensitivity, and detection limits $(1 \mathrm{nM})$ for the determination of saxitoxin with rapid response times (i.e., 5-20 $\mathrm{min}$ ) were noticed. The sensor was easily constructed and had adequate storage stability with a slope of $60 \mathrm{mV} /$ decade over saxitoxin concentration. The method was applied for the determination of STX in lake water and shellfish samples.

\subsection{Applications of the $\mathrm{ZnO}$ Nanoelectrode-Based Devices}

A potentiometric cholesterol device was constructed by immobilizing cholesterol oxidase into polymerized lipid membrane on $\mathrm{ZnO}$ nanowalls [75]. The enzyme was co-deposited into the lipid membrane prior to polymerization on the $\mathrm{ZnO}$ nanowalls surfaces, and provided a sensitive, selective, stable, and reproducible cholesterol device. The electrode slope was $57 \mathrm{mV} /$ decade of cholesterol. No interferences were noticed by ascorbic acid, glucose, urea, proteins, and lipids. The present biosensor has shown biocompatibility and could be implanted in the human body.

A uric acid electrochemical device was reported in the literature by immobilizing the enzyme uricase into polymerized lipid membranes on $\mathrm{Zn}$ nanowires [76]. The enzyme was co-deposited with the lipid membrane prior to polymerization on the surface of the electrode. The biosensor was sensitive, selective, stable, and reproducible. The presence of a cationic lipid in membranes has increased the electrode slope by two-fold. No interferences were observed by the presence of ascorbic acid, glucose, urea, proteins, and lipids.

$\mathrm{ZnO}$ nanowires (NWs) were tailored for the immobilization of glucose oxidase in order to fabricate a glucose sensor [85]. The high specific surface area and isoelectric point provide the electrode efficient immobilization of high concentration of acidic enzymes. The apparent Michaelis constants were adjusted by tailoring the thickness of the GOD/ZnO nanowire layer and the enzyme loading in the nanowires. Through this route, linear region of sensitivity and reaction rates could be obtained. The long-term stability of this biosensor was high due to the inorganic $\mathrm{ZnO}$ NWs.

Well-aligned $\mathrm{ZnO}$ nanowires were constructed on gold-coated plastic substrates using a low-temperature aqueous chemical growth method [86]. These arrays had 50-130 nm diameters and were applied to construct a urea biosensor using urease within the concentration range 0.1 to $100 \mathrm{mM}$ with logarithmic response. The electrode slope was $52.8 \mathrm{mV} /$ decade for $0.1-40 \mathrm{mM}$ of urea, and response times were less than $4 \mathrm{~s}$; this urea biosensor had excellent selectivity and reproducibility and showed no response to interferents such as ascorbic acid and uric acid, glucose, and $K(+)$ and $\mathrm{Na}(+)$ ions.

Well-aligned ZnO nanowires decorated with Pt nanoparticles (NPs) were recently used to construct a non-enzymatic glucose biosensor [87]. The use of Pt NPs decoration increased the sensitivity by 10-fold. The high specific surface area and isoelectric point (IEP) of $\mathrm{ZnO}$ has provided the electrode 
biocompatibility. A similar glucose biosensor on silicon NWs ( $\mathrm{ZnO} / \mathrm{Si} \mathrm{NWs})$ was also reported in the literature [88]. These nanowire nanocomposites have shown an excellent amperometric sensitivity to glucose $\left(129 \mu \mathrm{A} \cdot \mathrm{mM}^{-1}\right)$, low detection limits $(12 \mu \mathrm{M})$, good stability and reproducibility, and selectivity in the presence of common interferents. Recent works applied a roll-to-roll flexographic printing technique to construct a three-electrode electrochemical unit that consisted of $\mathrm{ZnO} N W s$ [89]. This unit exhibited a sensitivity of $1.2 \pm 0.2 \mu \mathrm{A} \cdot \mathrm{mM}^{-1} \cdot \mathrm{cm}^{-2}$ and the calibration graph was linear over the glucose concentration between 0.1 to $3.6 \mathrm{mM}$.

A ZnO NWs/Au electrode was constructed by immobilizing DNA for the fast detection of breast cancer 1 (BRCA1) gene [90]. This DNA biosensor was able to detect the target sequence in the concentration range between 10.0 and $100.0 \mu \mathrm{M}$, with a detection limit of $3.32 \mu \mathrm{M}$. A sensitive and selective label-free DNA ZnO NW device, which was based on a Schottky contacted, was also reported in the literature [91]. The performance of this device was greatly increased by the use of piezotronic effect [91].

\section{Challenges and Advances}

Regardless of the scope of research, lipid membrane platforms have become indispensable tools in biosensing and cell studies. Electrochemistry combined with photonics will most certainly provide an optimal for guiding lipid formation and monitoring membrane interactions [10]. Many challenges lie ahead, mostly referring to the minimization of matrix effects, membrane reproducibility, and sensor reliability [64].

Micro- and nanofabrication technology are expected to bring membrane biosensors in the market [92]. A critical issue that arises is the addition of a competitive advantage that could ensure a successful commercialization. Standardization of procedures will be a serious step towards the diffusion of membrane technology [93]. These many forms and formats of the bilayer should have a comparable basis that would easily match one membrane system with one application to facilitate technology transfer. Fabrication, validation, and long-term stability protocols should be developed, along with operation and storage specifications, energy demands, and autonomy capabilities.

The development of lipid-based platforms into nature-mimicking gustatory or olfactory arrays can rely on current chip integration techniques, but the extremely low detection limits required can be only achieved with ligand-gated ion channels, provided that technology advances in controlling protein orientation will become available in the near future [62]. Synthetic or engineered channels, with built-in guidance systems has been recently proposed [65] and might prove to be quite useful for mass production.

The possibility to construct interdigitated interfaces is expected to open the way for neuronal adhesion [94], with tremendous opportunities for 3D multi-microelectrode platforms [95]. Competitive transduction technologies and systems should become smaller and portable without compromising resolution and accuracy. Further, in situ imaging analysis should become available for mapping the transducer surface in order to measure the concentration and distribution of bioelements on the bilayer [96].

The biosensing concept of the bilayer lies on the interaction of the target analyte with a biological element or system. This pairing might not always be known or attainable; this is true for many environmental pollutants such as pesticides, herbicides, and insecticides [1,12]. More insight is required on the interaction of these species with the lipid membranes in order to devise bioelement-free sensing strategies. In order to grasp, in full, membrane functionality, the freely-suspended original platforms have been revisited and partly re-engineered with cushioned floating bilayers [49]. The concept that is expected to be realized in the near future is a free-standing, freely-suspended bilayer that is close to the transducer surface without interacting with it. 


\section{Conclusions and Future Prospects}

The nano-era has brought about many changes, many opportunities, and many prospects for advancing science and technology in many fields. This paper presented the current directions in the field of artificial lipid membrane platforms, more in an effort to attract new researchers in the field than to present an exhaustive description of recent accounts.

The paper describes the recent platforms that are based on lipid membranes and used for food, environmental, and clinical analysis. These technologies include the construction of stable-in-solution and in-air lipid membranes, and that are supported on microfiber glass filters and are polymerized on graphene and $\mathrm{ZnO}$ microelectrodes. The polymeric lipid film devices can be portable and used in the field. These biosensors have detection limits in the $\mathrm{nM}$ concentrations. It is expected soon to commercially prepare units for market production.

The results have exhibited that these lipid membrane-based detectors can be stored and used after remaining in the air for periods of one month and can be easily constructed at low cost. The response times of these nanosensors are on the order of seconds and are not bulky and much cheaper than chromatographic units; these detectors can be complimentary to LC and gas chromatographic instruments for in-field applications, for the rapid detection of food and environmental toxicants and in clinical analysis. These toxicants include toxins, carbamates, hydrazines, hormones, polycyclic aromatic hydrocarbons, glucose, cholesterol, etc., with high sensitivity and selectivity, rapid response times, portability, etc.

Author Contributions: All authors contributed equally to this work.

Conflicts of Interest: The authors declare no conflicts of interest.

\section{References}

1. Siontorou, C.G.; Nikoleli, G.-P.; Nikolelis, D.P.; Karapetis, S.K. Artificial lipid membranes: Past, present, and future. Membranes 2017, 7, 38. [CrossRef]

2. Mazur, F.; Bally, M.; Städler, B.; Chandrawati, R. Liposomes and lipid bilayers in biosensors. Adv. Colloid Interface Sci. 2017, 249, 88-99. [CrossRef] [PubMed]

3. Su, Z.F.; Leitch, J.J; Lipkowski, J. Electrode-supported biomimetic membranes: An electrochemical and surface science approach for characterizing biological cell membranes. Curr. Opin. Electrochem. 2018, 12, 60-72. [CrossRef]

4. Gould, S.B. Membranes and evolution. Curr. Biol. 2018, 28, 381-385. [CrossRef] [PubMed]

5. Ebert, A.; Hannesschlaeger, C.; Goss, K.-U.; Pohl, P. Passive permeability of planar lipid bilayers to organic anions. Biophys. J. 2018, 115, 1931-1941. [CrossRef] [PubMed]

6. Vacek, J.; Zatloukalova, M.; Novak, D. Electrochemistry of membrane proteins and protein-lipid assemblies. Curr. Opin. Electrochem. 2018, 12, 73-80. [CrossRef]

7. Nikoleli, G.-P.; Nikolelis, D.P.; Evtugyn, G.; Hianik, T. Advances in lipid film based biosensors. TrAC Trends Anal. Chem. 2016, 79, 210-221. [CrossRef]

8. Raghunathan, K.; Kenworthy, A.K. Dynamic pattern generation in cell membranes: Current insights into membrane organization. BBA-Biomembranes 2018, 1860, 2018-2031. [CrossRef]

9. Kalyankar, N.D.; Sharma, M.K.; Vaidya, S.V.; Calhoun, D.; Maldarelli, C.; Couzis, A.; Gilchrist, L. Arraying of intact liposomes into chemically functionalized microwells. Langmuir 2006, 22, 5403-5411. [CrossRef] [PubMed]

10. Siontorou, C.G. Bilayer lipid membrane constructs: A strategic technology evaluation approach. In Advanced Bioelectronic Materials; Tiwari, A., Patra, H.K., Turner, A.P.F., Eds.; John Wiley \& Sons: Hoboken, NJ, USA, 2015; pp. 311-353.

11. Cranfield, C.G.; Cornell, B.A.; Grage, S.L.; Duckworth, P.; Carne, S.; Ulrich, A.S.; Martinac, B. Transient potential gradients and impedance measures of tethered bilayer lipid membranes: Pore-forming peptide insertion and the effect of electroporation. Biophys. J. 2014, 106, 182-189. [CrossRef] [PubMed]

12. Nikolelis, D.P.; Siontorou, C.G. Flow injection monitoring and analysis of mixtures of simazine, atrazine, and propazine using filter-supported bilayer lipid membranes (BLMs). Electroanalysis 1996, 8, 907-912. [CrossRef] 
13. Michaloliakos, A.I.; Nikoleli, G.P.; Siontorou, C.G.; Nikolelis, D.P. Rapid flow injection electrochemical detection of Arochlor 1242 using stabilized lipid membranes with incorporated sheep anti-PCB antibody. Electroanalysis 2012, 24, 495-501. [CrossRef]

14. Nikolelis, D.P.; Simantiraki, M.G.; Siontorou, C.G.; Toth, K. Flow injection analysis of carbofuran in foods using air stable lipid film based acetylcholinesterase biosensor. Anal. Chim. Acta 2005, 537, 169-177. [CrossRef]

15. Nikolelis, D.P.; Siontorou, C.G.; Krull, U.J.; Katrivanos, P.L. Ammonium ion minisensors from self-assembled bilayer lipid membranes using gramicidin as an ionophore. Modulation of ammonium selectivity by platelet-activating factor. Anal. Chem. 1996, 15, 1735-1741. [CrossRef]

16. Vallejo, A.E.; Gervasi, C.A. EIS studies of valinomycin-mediated K+ transport through supported lipid bilayers. J. Electroanal. Chem. 2007, 603, 51-58. [CrossRef]

17. Su, Z.F.; Shodiev, M.; Leitch, J.J.; Abbasi, F.; Lipkowski, J. Role of transmembrane potential and defects on the permeabilization of lipid bilayers by alamethicin, an ion-channel-forming peptide. Langmuir 2018, 34, 6249-6260. [CrossRef]

18. Pantoja, R.; Sigg, D.; Blunck, R.; Benzanilla, F.; Heath, J.R. Bilayer reconstitution of voltage-dependent ion channels using a microfabricated silicon chip. Biophys. J. 2001, 81, 2389-2394. [CrossRef]

19. Ben Chaim, Y.; Chanda, B.; Dascal, N.; Bezanilla, F.; Parnas, I.; Parnas, H. Movement of 'gating charge' is coupled to ligand binding in a G-protein-coupled receptor. Nature 2006, 444, 106-109. [CrossRef]

20. Klymchenko, A.S.; Mely, Y.; Demchenko, A.P.; Duportail, G. Simultaneous probing of hydration and polarity of lipid bilayers with 3-hydroxyflavone fluorescent dyes. BBA-Biomembranes 2004, 1665, 6-19. [CrossRef]

21. Klymchenko, A.S.; Duportail, G.; Mely, Y.; Demchenko, A.P. Ultrasensitive two-color fluorescence probes for dipole potential in phospholipid membranes. Proc. Natl. Acad. Sci. USA 2003, 100, 11219-11224. [CrossRef]

22. Starke-Peterkovic, T.; Turner, N.; Else, P.L.; Clarke, R.J. Electric field strength of membrane lipids from vertebrate species: Membrane lipid composition and Na+-K+-ATPase molecular activity. Am. J. Physiol. Regul. Integr. Comp. Physiol. 2005, 288, 663-670. [CrossRef]

23. Peterson, U.; Mannock, D.A.; Lewis, R.N.A.H.; Pohl, P.; McElhaney, R.N.; Pohl, E.E. Origin of membrane dipole potential: Contribution of the phospholipid fatty acid chains. Chem. Phys. Lipids 2002, 117, 19-27. [CrossRef]

24. Warshaviak, D.T.; Muellner, M.J.; Chachisvilis, M. Effect of membrane tension on the electric field and dipole potential of lipid bilayer membrane. Biochim. Biophys. Acta 2011, 1808, 2608-2617. [CrossRef]

25. Wiegand, G.; Arribas-Layton, N.; Hillebrandt, H.; Sackmann, E.; Wagner, P. Electrical properties of supported lipid bilayer membranes. J. Phys. Chem. B 2002, 106, 4245-4254. [CrossRef]

26. Legiň, M.; Laputková, G.; Sabo, J.; Vojčíková, L. Impedance Spectroscopy of Bilayer Lipid Membranes Self-assembled on Agar Support-Interaction with HDL. Physiol. Res. 2007, 56 (Suppl. 1), S85-S91.

27. Liu, X.; Li, L.; Mason, A.J. High-throughput impedance spectroscopy biosensor array chip. Philos. Trans. R. Soc. A 2014, 372, 20130107. [CrossRef]

28. Wüstner, D.; Sklenar, H. Atomistic Monte Carlo simulation of lipid membranes. Int. J. Mol. Sci. 2014, 15, 1767-1803. [CrossRef]

29. Xing, C.; Faller, R. What is the difference between a supported and a free bilayer? Insights from Molecular Modeling on Different Scales. In Advances in Planar Lipid Bilayers and Liposomes; Iglič, A., Ed.; Elsevier: Amsterdam, The Netherlands, 2010; pp. 127-157.

30. Khan, M.S.; Dosoky, N.S.; Williams, J.D. Engineering lipid bilayer membranes for protein studies. Int. J. Mol. Sci. 2013, 14, 21561-21597. [CrossRef]

31. Ackerman, D.G.; Feigenson, G.W. Lipid bilayers: Clusters, domains and phases. Essays Biochem. 2015, 57, 33-42. [CrossRef]

32. Siontorou, C.G.; Nikolelis, D.P.; Piunno, P.A.E.; Krull, U.J. Detection of DNA hybridization using self-assembled bilayer lipid membranes (BLMs). Electroanalysis 1997, 57, 1067-1071. [CrossRef]

33. Komura, S.; Shirotori, H.; Olmsted, P.D. Phase behaviour of three-component lipid mixtures. J. Phys. Condens. Matter 2005, 17, S2951-S2956. [CrossRef]

34. Komura, S.; Andelman, D. Physical aspects of heterogeneities in multi-component lipid membranes. Adv. Colloid Interface Sci. 2014, 208, 34-46. [CrossRef]

35. Dimitrov, D.S.; Jain, R.K. Membrane stability, Biochim. Biophys. Acta 1984, 779, 437-468. 
36. Siontorou, C.G.; Georgopoulos, K.N. A biosensor platform for soil management: The case of nitrites. J. Clean. Prod. 2016, 111, 133-142. [CrossRef]

37. Oshima, A.; Sumitomo, K. Vesicle fusion with bilayer lipid membrane controlled by electrostatic interaction. Biochem. Biophys. Rep. 2017, 11, 58-63. [CrossRef]

38. Richter, R.; Mukhopadhyay, A.; Brisson, A. Pathways of lipid vesicle deposition on solid surfaces: A combined QCM-D and AFM study. Biophys. J. 2003, 85, 3035-3047. [CrossRef]

39. Morigaki, K.; Tawa, K. Vesicle fusion studied by surface plasmon resonance and surface plasmon fluorescence spectroscopy. Biophys. J. 2006, 91, 1380-1387. [CrossRef]

40. Rebaud, S.; Maniti, O.; Girard-Egrot, A.P. Tethered bilayer lipid membranes (tBLMs): Interest and applications for biological membrane investigations. Biochimie 2014, 107, 135-142. [CrossRef] [PubMed]

41. Kongsuphol, O.; Fang, K.B.; Ding, Z. Lipid bilayer technologies in ion channel recordings and their potential in drug screening assay. Sens. Actuators B Chem. 2013, 185, 530-542. [CrossRef]

42. Schuster, B.; Pum, D.; Sleytr, U.B. S-layer stabilized lipid membranes. Biointerphases 2008, 3, FA3-FA11. [CrossRef]

43. Römer, W.; Steinem, C. Impedance analysis and single-channel recordings on nano-black lipid membranes based on porous alumina. Biophys. J. 2004, 86, 955-965.

44. Siontorou, C.G.; Nikolelis, D.P.; Krull, U.J. Flow injection monitoring and analysis of mixtures of hydrazine compounds using filter-supported bilayer lipid membranes with incorporated DNA. Anal. Chem. 2000, 72, 180-186. [CrossRef]

45. Andersson, M.; Keizer, H.M.; Zhu, C.; Fine, D.; Dodabalapur, A.; Duran, R.S. Detection of single ion channel activity on a chip using tethered bilayer membranes. Langmuir 2007, 23, 2924-2927. [CrossRef]

46. Phung, T.; Zhang, Y.; Dunlop, J.; Dalziel, J. Bilayer lipid membranes supported on Teflon filters: A functional environment for ion channels. Biosens. Bioelectron. 2011, 26, 3127-3135. [CrossRef] [PubMed]

47. Zhang, Y.; Chen, Y.; Jin, G. Chitosan cushioned phospholipid membrane and its application in imaging ellipsometry based-biosensor. Appl. Surf. Sci. 2011, 257, 9407-9413. [CrossRef]

48. Kibrom, A.; Roskamp, R.F.; Jonas, U.; Menges, B.; Knoll, W.; Paulsen, H.; Naumann, R.L.C. Hydrogel-supported protein-tethered bilayer lipid membranes: A new approach toward polymer-supported lipid membranes. Soft Matter 2011, 7, 237-246. [CrossRef]

49. Shoaib, T.; Nalam, P.C.; He, Y.; Chen, Y.; Espinosa-Marzal, R.M. Assembly, morphology, diffusivity, and indentation of hydrogel-supported lipid bilayers. Langmuir 2017, 33, 7105-7117. [CrossRef] [PubMed]

50. Khomutov, G.B.; Kim, V.P.; Potapenkov, K.V.; Parshintsev, A.A.; Soldatov, E.S.; Usmanov, N.N.; Saletsky, A.M.; Sybachin, A.V.; Yaroslavov, A.A.; Migulin, V.A.; et al. Langmuir monolayers and Langmuir-Blodgett films of pH-sensitive lipid. Colloids Surf. A 2017, 532, 150-154. [CrossRef]

51. Chen, X.; Lenhert, S.; Hirtz, M.; Lu, N.; Fuchs, H.; Chi, L. Langmuir-Blodgett patterning: A bottom-up way to build mesostructures over large areas. Acc. Chem. Res. 2007, 40, 393-401. [CrossRef]

52. Siontorou, C.G.; Georgopoulos, K.N.; Nikoleli, G.P.; Nikolelis, D.P.; Karapetis, S.K.; Bratakou, S. Protein-based graphene biosensors: Optimizing artificial chemoreception in bilayer lipid membranes. Membranes 2016, 6, 43. [CrossRef] [PubMed]

53. Wilk, S.J.; Petrossian, L.; Goryll, M.; Thornton, T.J.; Goodnick, S.M.; Tang, J.M.; Eisenberg, R.S. Integrated electrodes on a silicon based ion channel measurement platform. Biosens. Bioelectron. 2008, 23, 183-190. [CrossRef] [PubMed]

54. Suzuki, H.; Tabata, K.V.; Noji, H.; Takeuchi, S. Electrophysiological recordings of single ion channels in planar lipid bilayers using a polymethyl methacrylate microfluidic chip. Biosens. Bioelectron. 2007, 22, 1111-1115. [CrossRef]

55. Reimhult, E.; Baumann, M.; Kaufmann, S.; Kumar, K.; Spycher, P. Advances in nanopatterned and nanostructured supported lipid membranes and their applications. Biotechnol. Genet. Eng. Rev. 2010, 27, 185-216. [CrossRef] [PubMed]

56. Lenhert, S.; Sun, P.; Wang, Y.; Fuchs, H.; Mirkin, C. Massively parallel dip-pen nanolithography of heterogeneous supported phospholipid multilayer patterns. Small 2007, 3, 71-75. [CrossRef]

57. Furukawa, K.; Aiba, T. Supported lipid bilayer composition microarray fabricated by pattern-guided self-spreading. Langmuir 2011, 27, 7341-7344. [CrossRef]

58. Heath, G.R.; Li, M.; Rong, H.; Radu, V.; Frielingsdorf, S.; Lenz, O.; Butt, J.N.; Jeuken, L.J. Multilayered lipid membrane stacks for biocatalysis using membrane enzymes. Adv. Funct. Mater. 2017, 27, 1606265. [CrossRef] 
59. Penkauskas, T.; Preta, G. Biological applications of tethered bilayer lipid membranes. Biochimie 2019, 157, 131-141. [CrossRef] [PubMed]

60. Revzin, A.; Maverakis, E.; Chang, H.C. Biosensors for immune cell analysis-A perspective. Biomicrofluidics 2012, 6, 021301. [CrossRef]

61. Diculescu, V.C.; Chiorcea-Paquim, A.-M.; Oliveira-Brett, A.M. Applications of a DNA-electrochemical biosensor. Trends Anal. Chem. 2016, 79, 23-36. [CrossRef]

62. Osaki, T.; Takeuchi, S. Artificial cell membrane systems for biosensing applications. Anal. Chem. 2017, 89, 216-231. [CrossRef] [PubMed]

63. Misawa, N.; Osaki, T.; Takeuchi, S. Membrane protein-based biosensors. J. R. Soc. Interface 2018, 15, 20170952. [CrossRef]

64. Nikoleli, G.P.; Nikolelis, D.P.; Siontorou, C.G.; Karapetis, S. Lipid membrane nanosensors for environmental monitoring: The art, the opportunities, and the challenges. Sensors 2018, 18, 284. [CrossRef] [PubMed]

65. Andreou, V.G.; Nikolelis, D.P. Flow injection monitoring of aflatoxin $\mathrm{M}_{1}$ in milk and milk preparations using filter-supported bilayer lipid membranes. Anal. Chem. 1998, 70, 2366-2371. [CrossRef] [PubMed]

66. Nikolelis, D.P.; Siontorou, C.G.; Andreou, V.G.; Krull, U.J. Stabilized bilayer-lipid membranes for flow-through experiments. Electroanalysis 1995, 7, 531-536. [CrossRef]

67. Nikolelis, D.P.; Raftopoulou, G.; Nikoleli, G.-P.; Simantiraki, M. Stabilized lipid membrane based biosensors with incorporated enzyme for repetitive uses. Electroanalysis 2006, 18, 2467-2474. [CrossRef]

68. Nikolelis, D.P.; Raftopoulou, G.; Chatzigeorgiou, P.; Nikoleli, G.-P.; Viras, K. Optical portable biosensors based on stabilized lipid membrane for the rapid detection of doping materials in human urine. Sens. Actuators B Chem. 2008, 130, 577-582. [CrossRef]

69. Nikoleli, G.-P.; Israr, M.Q.; Tzamtzis, N.; Nikolelis, D.P.; Willander, M.; Psaroudakis, N. Structural characterization of graphene nanosheets for miniaturization of potentiometric urea lipid film based biosensors. Electroanalysis 2012, 24, 1285-1295. [CrossRef]

70. Bratakou, S.; Nikoleli, G.-P.; Nikolelis, D.P.; Psaroudakis, N. Development of a potentiometric chemical sensor for the rapid detection of carbofuran based on air stable lipid films with incorporated calix[4]arene phosphoryl receptor using graphene electrodes. Electroanalysis 2015, 27, 2608-2613. [CrossRef]

71. Bratakou, S.; Nikoleli, G.-P.; Siontorou, C.G.; Nikolelis, D.P.; Tzamtzis, N. Electrochemical biosensor for naphthalene acetic acid in fruits and vegetables based on lipid films with incorporated auxin-binding protein receptor using graphene electrodes. Electroanalysis 2016, 28, 2171-2177. [CrossRef]

72. Karapetis, S.; Nikoleli, G.-P.; Siontorou, C.G.; Nikolelis, D.P.; Tzamtzis, N.; Psaroudakis, N. Development of an electrochemical biosensor for the rapid detection of cholera toxin based on air stable lipid films with incorporated ganglioside GM1 using graphene electrodes. Electroanalysis 2016, 28, 1584-1590. [CrossRef]

73. Bratakou, S.; Nikoleli, G.-P.; Siontorou, G.C.; Nikolelis, D.P.; Karapetis, S.; Tzamtzis, N. Development of an electrochemical biosensor for the rapid detection of saxitoxin based on air stable lipid films with incorporated Anti-STX using graphene electrodes. Electroanalysis 2017, 29, 990-997. [CrossRef]

74. Naval, A.P.; Katzenmeyer, A.M.; Gosho, Y.; Tekin, B.; Islam, M.S. Sonochemical approach for rapid growth of zinc oxide nanowalls. Appl. Phys. A 2012, 107, 661-667.

75. Psychoyios, V.N.; Nikoleli, G.-P.; Tzamtzis, N.; Nikolelis, D.P.; Psaroudakis, N.; Danielsson, B.; Israr, M.Q.; Willander, M. Potentiometric cholesterol biosensor based on $\mathrm{ZnO}$ nanowalls and stabilized polymerized lipid film. Electroanalysis 2013, 25, 367-372. [CrossRef]

76. Usman Ali, S.M.; Alvi, N.H.; Ibupoto, Z.; Nur, O.; Willander, M.; Danielsson, B. Selective potentiometric determination of uric acid with uricase immobilized on $\mathrm{ZnO}$ nanowires. Sens. Actuators B 2011, 152, 241-247. [CrossRef]

77. Vaface, M.; Youzbashizade, H. Production of zinc oxide nanoparticles by liquid phase processing: An investigation on optical properties. Mater. Sci. Forum 2007, 553, 252-256. [CrossRef]

78. Tzamtzis, N.; Psychoyios, V.N.; Nikoleli, G.-P.; Willander, M.; Qadir Israr, M. Flow Potentiometric Injection Analysis of Uric Acid Using Lipid Stabilized Films with Incorporated Uricase on ZnO Nanowires. Electroanalysis 2012, 24, 1719-1725. [CrossRef]

79. Nikolelis, D.P.; Andreou, V.G. Electrochemical transduction of interactions of atrazine with bilayer lipid membranes. Electroanalysis 2005, 8, 643-647. [CrossRef] 
80. Nikolelis, D.P.; Raftopoulou, G.; Simantiraki, M.; Psaroudakis, N.; Nikoleli, G.-P.; Hianik, T. Preparation of a selective receptor for carbofuran for the development of a simple optical spot test for its rapid detection using stabilized in air lipid films with incorporated receptor. Anal. Chim. Acta 2008, 620, 134-141. [CrossRef] [PubMed]

81. Nikolelis, D.P.; Ntanos, N.; Nikoleli, G.-P.; Tampouris, K. Development of an electrochemical biosensor for the rapid detection of naphthalene acetic acid in fruits by using air stable lipid films with incorporated auxin-binding protein 1 receptor. Protein Pept. Lett. 2008, 15, 789-794. [CrossRef]

82. Nikolelis, D.P.; Raftopoulou, G.; Psaroudakis, N.; Nikoleli, G.-P. Development of an electrochemical chemosensor for the rapid detection of zinc based on air stable lipid films with incorporated calix4arene phosphoryl receptor. Int. J. Environ. Anal. Chem. 2009, 89, 211-222. [CrossRef]

83. Nikoleli, G.-P.; Siontorou, C.G.; Nikolelis, D.P.; Bratakou, S.; Karapetis, S.; Tzamtzis, N. Biosensors based on lipid modified graphene microelectrodes. Carbon 2017, 3, 9. [CrossRef]

84. Nikoleli, G.-P.; Nikolelis, D.P.; Tzamtzis, N. Development of an electrochemical biosensor for the rapid detection of cholera toxin using air stable lipid films with incorporated ganglioside GM1. Electroanalysis 2011, 23, 2182-2189. [CrossRef]

85. Zang, J.; Li, C.M.; Cui, X.; Wang, J.; Sun, X.; Dong, H.; Sun, C.Q. Tailoring Zinc Oxide Nanowires for High Performance Amperometric Glucose Sensor. Electroanalysis 2007, 19, 1008-1014. [CrossRef]

86. Ali, S.M.U.; Ibupoto, Z.H.; Salman, S.; Nur, O.; Willander, M.; Danielsson, B. Selective determination of urea using urease immobilized on $\mathrm{ZnO}$ nanowires. Sens. Actuators B 2011, 160, 637-643. [CrossRef]

87. Hsu, C.L.; Lin, J.H.; Hsu, D.X.; Wang, S.H.; Lin, S.Y.; Hsueh, T.J. Enhanced non-enzymatic glucose biosensor of $\mathrm{ZnO}$ nanowires via decorated Pt nanoparticles and illuminated with UV/green light emitting diodes. Sens. Actuators B. 2017, 238, 150-159. [CrossRef]

88. Miao, F.; Lu, X.; Tao, B.; Li, R.; Chu, P.K. Glucose oxidase immobilization platform based on ZnO nanowires supported by silicon nanowires for9glucose biosensing. Microelectron. Eng. 2016, 149, 153-158. [CrossRef]

89. Fung, C.M.; Lloyd, J.S.; Samavat, S.; Deganello, D.; Teng, K.S. Facile fabrication of electrochemical ZnO nanowire glucose biosensor using roll to roll printing technique. Sens. Actuators B 2017, 247, 807-813. [CrossRef]

90. Mansor, N.A.; Zain, Z.M.; Hamzah, H.H.; Noorden, M.S.A.; Jaapar, S.S.; Beni, V.; Ibupoto, Z.H. Detection of Breast Cancer 1 (BRCA1) gene using an electrochemical DNA biosensor based on immobilized ZnO nanowires. Open J. Appl. Biosens. 2014, 3, 9-17. [CrossRef]

91. Cao, X.; Cao, X.; Guo, H.; Li, T.; Jie, Y.; Wang, N.; Wang, Z.L. Piezotronic effect enhanced label-free detection of DNA using a schottky-contacted ZnO nanowire biosensor. ACS Nano 2016, 10, 8038-8044. [CrossRef]

92. Burns, J.R.; Seifert, A.; Fertig, N.; Howorka, S. A biomimetic DNA-based channel for the ligand-controlled transport of charged molecular cargo across a biological membrane. Nat. Nanotechnol. 2016, 11, 152-156. [CrossRef]

93. Siontorou, C.G.; Batzias, F.A. A methodological combined framework for roadmapping biosensor research: A fault tree analysis approach within a strategic technology evaluation frame. Crit. Rev. Biotechnol. 2013, 34, 31-55. [CrossRef] [PubMed]

94. Moulick, R.G.; Panaitov, G.; Choi, S.E.; Mayer, D.; Offenhausser, A. Patterning artificial lipid bilayer on nanostructured surfaces. Int. J. Nanomed. 2018, 13, 55-58. [CrossRef] [PubMed]

95. Lee, S.; Lee, C. Toward advanced neural interfaces for the peripheral nervous system (PNS) and their future applications. Curr. Opin. Biomed. Eng. 2018, 6, 130-137. [CrossRef]

96. Bizzotto, D.; Burgess, I.J.; Doneux, T.; Sagara, T.; Yu, H.-Z. Beyond simple cartoons: Challenges in characterizing electrochemical biosensor interfaces. ACS Sens. 2018, 3, 5-12. [CrossRef] [PubMed]

(C) 2019 by the authors. Licensee MDPI, Basel, Switzerland. This article is an open access article distributed under the terms and conditions of the Creative Commons Attribution (CC BY) license (http://creativecommons.org/licenses/by/4.0/). 